\title{
Ciclopirox Olamine Oral
}

National Cancer Institute

\section{Source}

National Cancer Institute. Ciclopirox Olamine Oral. NCI Thesaurus. Code C91375.

An aqueous suspension of the olamine salt form of ciclopirox, a synthetic, broadspectrum hydroxypyridone antifung al agent with additional antibacterial and antiinflammatory activities. Although the exact mechanism of action of ciclopirox has yet to be fully elucidated, this agent is able to chelate trivalent cations, such as $\mathrm{Fe} 3+$, thereby inhibiting the availability of essential co-factors for enzymes. This may lead to a loss of activity of enzymes that are essential for cellular metabolism, organization of cell wall structure and other crucial cell functions. In addition, ciclopirox exerts its antiinflammatory activity by inhibiting 5-lipoxygenase and cyclooxygenase (COX). 